\title{
Awareness and Usage of E-Learning Materials among Students of National Open University of Nigeria (NOUN)
}

\author{
Nwana S.E. ${ }^{1, *}$, Egbe C. I. ${ }^{2}, \&$ Ugwuda, S.O. ${ }^{2}$ \\ ${ }^{1}$ Faculty of Education, Nnamdi Azikiwe University, Awka, Nigeria \\ ${ }^{2}$ Faculty of Education, University of Nigeria, Nsukka, Nigeria \\ *Correspondence: Department of Educational Foundations, Nnamdi Azikiwe University, Faculty of Education, \\ Awka, Anambra State, Nigeria. E-mail: helenadebola95@yahoo.com
}

Received: October 23, 2017

Accepted: December 4, 2017 Online Published: December 23, 2017

doi:10.5430/wje.v7n6p75

URL: https://doi.org/10.5430/wje.v7n6p75

\begin{abstract}
The study focused on awareness and usage of e-learning materials among students in the distance education programme of the National Open University of Nigeria (NOUN). The study is a descriptive survey which was guided by two research questions. The population for the study comprised of the 1, 512 year three students out of which 400 were sampled and used for the study. The instrument for data collection was a 30-item self-constructed checklist titled, "Distance Education Students' Awareness and Usage of E-Learning Materials" (DESAUELM). It was validated by experts and the reliability co-efficient stood at 0.86 . The data collected were analysed using frequencies and percentages. The findings showed that, the students are aware of majority of the e-learning materials. Also, the result on usage indicated that the students do not use majority of the e-learning materials. There was general low usage of the e-learning materials as revealed by the findings.
\end{abstract}

Keywords: awareness; usage; e-learning materials

\section{Introduction}

The National Open University of Nigeria (NOUN) was established and backed up with the National Open University Act of 1983. The Act was reactivated in 2001 and twenty-seven study centres were opened up in different parts of the country. The centres were to run distance education programmes for learners scattered in various geographical distances. The Open/Distance education is an innovation in the Nigerian Educational System. It was introduced to make education accessible to all at undergraduate and postgraduate degree levels. It is a learning programme in which the learners are removed in time and space from the leaders. Makinde (2008) defined it as the type of correspondence education in which the teachers is at a distance from the learners who include: those who live in geographically isolated areas, shift workers, physically and socially handicapped e.g prisoners, refugees/victims of natural disasters; and those who are too old to return to the formal school system.

The Federal Republic of Nigeria (FRN, 2014) in the National Policy on Education caps it all as follows:

(a) Open/Distance education is the mode of teaching in which learners are removed in time and space from the teachers;

(b) It uses a variety of media and technologies to provide and/or improve access to good quality education for large number of learners wherever they may be.

The government has been making efforts for advancement in the field of distance education to ensure that the objectives of distance education which includes learning for those who dropped out and want to re-enter school are achieved. Some educational institutions in Nigeria were involved in it some years back. They are: the correspondent open study unit (COSU) in Lagos, Exams success correspondence college in Onitsha, Uni-Air programme of IMT in Enugu; and Uni-Air programme of the then school of Arts and Science (now Federal Polytechnic) in Oko, Anambra State.

In contemporary times, the age of information and communications technology (ICT), e-learning is involved in distance education. E-learning means electronically - assisted learning or learning with and through the use of 
electronic technologies. These authors, Nwana (2009) and Robinson (2009) pointed out that e-learning can take the form of courses as well as modules and can be delivered through the internet, intranet and extranet. Terms associated with e-learning are: online learning, virtual learning, digital learning and computer assisted learning. In distance education, various e-learning materials are used namely: computer, internet and e-mail, direct Broadcast Satellite (DBS), Digital Satellite System (DSS), videophone systems, teleconferencing devices, pocket switching, electronic boards, educational robots and multimedia systems e.g the mm projector (Nwana, 2009; \& Nwana, Ugwoegbu \& Oraegbunam, 2011).

E-learning incorporates pedagogy and it has become a new model of education in distance programmes for students in various geographical locations. The students are to use e-learning technologies in their study since they are separated from the teacher in time and space but many of the times, they rush down to the campus seeking for help in the use of emergent technologies in learning. This shows that the students are being challenged in the use of modem multimedia technologies in education. It is against this background that the present study seeks to find out the students' awareness and usage of e-learning materials in the National Open University of Nigeria (NOUN).

\section{Purpose}

The study sets to determine:

1. The e-learning materials which the students of distance education programme of the National Open University of Nigeria (NOUN) are aware of in learning.

2. The e-learning materials which the students of distance education programme of the National Open University of Nigeria (NOUN) use in learning.

\section{Research Questions}

1. What are the e-learning materials which the students of distance education are aware of for their learning?

2. What e-learning materials do students of distance education use in their learning?

\section{Method}

The study adopted descriptive survey research design. According to Nworgu (2015), a survey research design is one in which a group of people or items are being studied by collecting and analyzing data from only a few people or items considered to be representative of the entire population. The study was carried out in south-east Nigeria in four NOUN study centres namely: Awka (Abagana), Enugu in Enugu State, Owerri (Nekede) in Imo State and Umudike in Abia State. The population for the study comprised on the 1,512 year three students out of which 400 were sampled and used for the study. The instrument for data collection was a checklist titled "Distance Education Students Awareness and Usage of E-learning Materials" (DESAUELM). It has sections A and B with a total of 30 items which sought information on the two research questions.

There was both face and content validations of the instrument by experts. The Cronbach Alpha was used to determine the reliability of the instrument. A reliability co-efficient of 0.81 was obtained, an indication that the instrument was reliable fro data collection. In distributing the copies of the questionnaire, the researcher with three trained research assistants adopted the technique of on-the-spot distribution and collection. This ensured a $100 \%$ return rate. In analyasing the data, frequency distribution and percentages were used. The acceptable level of percentage was $50 \%$ and above for items indicating positive that is, Aware (A) and for items indicating in Use (IU). On the other hand, any item which scored below $50 \%$ was regarded as negative that is, Not Aware (NA) and Not in Use (NIU).

\section{Findings}

Research Question I: What are the e-learning materials which the students of distance education are aware of for their learning? 
Table 1. Frequencies and Percentages of Students' Responses on Their Awareness of E-Learning Materials for Learning

\begin{tabular}{lllll}
\multicolumn{1}{c}{ N=400 } & \multicolumn{3}{c}{} \\
\hline S/N & AWARENESS & \multicolumn{2}{c}{ STUDENTS } & \\
\cline { 3 - 4 } & Items & Freq & \% & Decision \\
\hline 1 & Computer: laptop, palmtop, notebook, Tablet and pocket computers & 387 & 96.8 & $\mathrm{~A}$ \\
2 & Internet and e-mail & 385 & 96.3 & $\mathrm{~A}$ \\
3 & Videophone systems & 289 & 72.3 & $\mathrm{~A}$ \\
4 & Teleconferencing devices & 296 & 74 & $\mathrm{~A}$ \\
5 & Direct Broadcast Satellite (DBS) for learning & 288 & 72 & $\mathrm{~A}$ \\
6 & Digital Satellite Systems (DSS) for learning & 281 & 70.3 & $\mathrm{~A}$ \\
7 & Courseware e.g CD-Rom, flash memories and slides & 377 & 94.3 & $\mathrm{~A}$ \\
8 & E-readers and e-books & 339 & 84.6 & $\mathrm{~A}$ \\
9 & E-graphics board for sketches and diagrams & 322 & 80.5 & $\mathrm{~A}$ \\
10 & Multimedia Systems e.g Multimedia (mm) projector & 345 & 86.3 & $\mathrm{~A}$ \\
11 & Digital /internet library & 380 & 95 & $\mathrm{~A}$ \\
12 & Digital laboratory & 275 & 68.3 & $\mathrm{~A}$ \\
13 & Hypertext and hypermedia for new discoveries in learning & 137 & 34.3 & NA \\
14 & Bluetooth devices for fast downloading of learning materials & 351 & 87.8 & $\mathrm{~A}$ \\
15 & Educational robots/Artificial Intelligent devices for learning & 340 & 85 & $\mathrm{~A}$ \\
& Cluster Total & & & \\
& Cluster \% & & 79.9 & \\
\hline
\end{tabular}

\section{Key: A $\quad$ Aware}

NA $=$ Not Aware

Table one shows that the respondents affirmed that they are aware of all the items except item 13 which boardered on hypertext and hypermedia for new discoveries in learning. The table indicated that they are aware of majority of the items which included computer, internet and e-mail, videophone systems and teleconferencing devices among others. These items scored above $50 \%$ which is the acceptable level for awareness. The cluster percentage for awareness is $79.9 \%$.

Research Question 2: What e-learning materials do students of distance education use in their learning?

Table 2: Frequencies and Percentages of Students' Responses on Their Usage of E-Learning Materials for Learning.

\begin{tabular}{|c|c|c|c|c|}
\hline \multicolumn{5}{|c|}{$\mathbf{N}=\mathbf{4 0 0}$} \\
\hline \multirow[t]{2}{*}{$\mathbf{S} / \mathbf{N}$} & \multirow[t]{2}{*}{ USAGE } & \multicolumn{2}{|c|}{ STUDENTS } & \multirow[b]{2}{*}{ Decision } \\
\hline & & Freq & $\%$ & \\
\hline 1 & Computer: laptop, palmtop, notebook, Tablet and pocket computers & 209 & 52.3 & IU \\
\hline 2 & Internet and e-mail & 260 & 65 & IU \\
\hline 3 & Videophone systems & 104 & 26 & NIU \\
\hline 4 & Teleconferencing devices & 121 & 30.3 & NIU \\
\hline 5 & Direct Broadcast Satellite (DBS) for learning & 92 & 23 & NIU \\
\hline 6 & Digital Satellite Systems (DSS) for learning & 101 & 25.3 & NIU \\
\hline 7 & Courseware e.g CD-Rom, flash memories and slides & 254 & 63.5 & IU \\
\hline 8 & E-readers and e-books & 119 & 29.3 & NIU \\
\hline 9 & E-graphics board for sketches and diagrams & 125 & 31.3 & NIU \\
\hline 10 & Multimedia Systems e.g Multimedia (mm) projector & 205 & 51.3 & IU \\
\hline 11 & Digital/internet library & 127 & 31.8 & NIU \\
\hline 12 & Digital laboratory & 17 & 4.3 & NIU \\
\hline 13 & Hypertext and hypermedia for new discoveries in learning & 15 & 3.8 & NIU \\
\hline 14 & Bluetooth devices for fast downloading of learning materials & 260 & 65 & IU \\
\hline \multirow[t]{2}{*}{15} & $\begin{array}{l}\text { Educational robots/Artificial Intelligent devices for learning } \\
\text { Cluster Total }\end{array}$ & 62 & 15.5 & NIU \\
\hline & Cluster \% & & 34.5 & \\
\hline
\end{tabular}

Key: $\quad$ IU $=$ In Use

NIU $=$ Not in Use 
Table 2 revealed that the respondents do not use majority of the items in learning. Out of the 15 items stated for usage, only five are being used. Majority of the materials as indicate in items 3,4,5,6,8,9,11,12,13 and 15 are not being used. These items scored below $50 \%$ which is the acceptable level for usage. The cluster percentage for usage is $34.5 \%$.

\section{Discussion}

The findings of the study as shown in table 1 revealed that the respondents are aware of 14 out of 15 items slated to answer research question one. These are items: 1, 2, 3, 4,5,6,7,8,9,10,11,12,14 and 15. They are computer, internet and e-mail, videophone systems, teleconferencing devices, Direct Broadcast Satellite (DBS), Digital Satellite Systems (DSS) courseware, e-readers and e-books, e-graphics board, multimedia projector, digital library, digital laboratory, Bluetooth devices and educational robots. These items scored above $50 \%$ which is the acceptable level for awareness. The cluster percentage for awareness is $79.9 \%$. This indicates that the respondents are aware of majority of the items.

The finding agrees with Olasina (2012) who studied students' e-learning experiences in Nigerian Universities and reported high awareness of e-learning resources among the students. The findings is consistent with Fabumni (2012) who studied undergraduates awareness of ICT resources in learning in Ekiti State University and found that the students are aware of media technologies in learning. The finding resonates with the research reports of Anejo (2007) who conducted a research using students of National Teachers Institute (NTI) and found that they are aware of emergent instructional technologies.

Table 2 which addressed research question 2 on students' usage of e-learning materials indicated that few materials are being used by the students. That is five out of fifteen. All the other items: 3,4,5,6,8,9,11,12,13 and 15 are not being used. They are videophone systems, teleconferencing devices, Direct Broadcast Satellite (DBS), Digital Satellite Systems (DSS), e-readers and e-books, e-graphics board, digital library, digital laboratory, hypertext and hypermedia, and educational robots. These items scored below $50 \%$ which is the acceptable level for usage. The cluster percentage for usage is $34.5 \%$. This indicates that the respondents are not using majority of the items.

The finding is in conformity with Lovillard (2008) who studied students' use of new technologies in learning and found that, the students could not use the computer to write and submit their assignments online, and for online collaborative learning and feedback. The finding matches that of Olibie and Akudolu (2009) who studied digital empowerment of the youths in higher institutions in south eastern Nigeria and found that, low percentage of the students use virtual resources and that, it might take Nigerian students 30 years to be empowered digitally to catch up with even South Africa, and 50 years to catch up with America.

The finding is similar to Nbina, Obomanu and Vikoo (2011) who conducted a research on students' utilization of ICT resources in Rivers State University of Education and discovered that the students have poor usage of ICT resources in learning. The finding is congruent with Jegede and Owolabi (2008) who conducted a study on students use of computer in Nigerian Secondary Schools and found that, almost $80 \%$ of the students interviewed agreed that they could not use or operate computers for learning. The finding is similar to Nwana (2012) who reported that teachers do not use majority of the e-learning materials for teaching in the secondary schools.

\section{Conclusion}

The National Open University of Nigeria (NOUN) runs distance education programme at undergraduate and postgraduate degree levels. The programme involve students who are in various geographical locations that are separated in time and space from the teacher. Many of the students are shift workers and some who dropped at a level of education and want to re-enter school for completion of their programme. Owing to the nature of their programme, they need a variety of media technologies for their learning. In this age of ICT, the media technologies go by the name e-learning materials. Some of them are computer (laptop, palmtop, notebook, tablet and pocket computers), internet and e-mail, e-readers and e-books among others. The result of the findings revealed that the students are aware of majority of the e-learning materials for learning; and in terms of usage, that the students do not use majority of the e-learning materials. This means that usage is where the problem lies.

\section{Recommendations}

The study recommends as follows: 
1. Since the students indicated awareness in majority of the e-learning materials, the government should sustain the awareness by creation of more ICT parks, e-learning resources centres and cyber cafés. This would make the students hold on to the awareness which they have in e-learning materials.

2. The study revealed that there was generally low usage of e-learning materials by the students. Therefore, the government should procure adequate e-learning resources needed in distance education such as internet computers, videophone systems and teleconferencing devices Direct Broadcast Satellite (DBS) and Digital Satellite Systems among others. The students will be exposed to their operative techniques

3. To encourage usage of the materials among the students, the government should encourage the students to go for training on the use of e-learning materials in various ICT parks and e-learning centres. The training should be free so as to ensure students participation.

4. The government should ensure that electricity is supplied on regular basis for the use of e-learning materials. This should be done through the use of UPS devices and standby generators.

5. There should be criteria for selecting the best student on the use of e-learning resources. At the end of the session, prizes/awards should be given for encouragement.

\section{References}

Anejo, E.E. (2007). The National teachers institute distance learning programme for the Nigerian certificate in education. The Benue State experience. Multi-Disciplinary Journal of Research Development, 8(4), 8-12.

Fabumni, F.A. (2012). Undergraduate Students' perception of the effectiveness of ICT use in improving teaching and learning in Ekiti State University, Ado-Ekiti. International Journal of Library and Information Science, 4(7), $121-130$

Federal Republic of Nigeria (FRN,2014). National Policy on Education. Lagos: NERDC press.

Jegede, P.O., \& Owolabi, A.J. (2008). Computer education in Nigerian secondary schools: Gaps between policy and practice. Retrieved from http://document/pdf/ict.com

Lovillard, D. (2008) New technologies, students and the curriculum. Journal of Communications and Information Technology in Higher Education, 2(1), 153-162.

Makinde, O. (2008). Towards effective educational technology in the distance learning system. In Oguranti, A. (ed.) Problems and problems of educational technology in Nigeria. Ibadan: Heinemann.

Nbina, J.B., Obomanu, B.J., \& Vikoo, B. (2011). Utilization of information and communication technology for quality instruction in Rivers State University of Education, Port Harcourt: An assessment. Journal of Emerging Trends in Educational Research and Policy Stuides, 2(1), 74-8.

Nwana, S.E. (2009). Impediments to effective implementation of the National Open University in an age of computer technology. Nigerian Journal of Research and Production, 15(1), 180-11

Nwana, S.E. (2012). Challenges in the application of e-learning by secondary school teachers in Anambra State, Nigeria. African Journal of Teacher Education (AJOTE), 2(1), 14-22.

Nwana, S.E., Ugwoegbu, I.T., \& Oraegbunam N., (2011). E-learning and curriculum implementation in computer age: problems and prospects. Unizik Orient Journal of Education, 6(1\&2), 97-103. https://doi.org/10.21083/ajote.v2i1.1913

Nworgu, B.G. (2015). Educational Research: Basic Issues and Methodology. Nsukka: University Trust Pub.

Olasina, S. (2012). Students' e-learning/m-learning. Experience and impact on motivation in Nigeria. Proceedings of the IATUL Conference. Retrieved from http://docs. libpurdue. Edu/ iatu/2012/papers, May 17th,2017

Olibie, E.I., \& Akudolu, L.R. (2009). Digital empowerment of youths in Higher Institutions in South-east of Nigeria. Journal of Educational Review, 2(3), 387-393.

Robinson, B. (2009). Media and technology in European distance education. Milton Keynes: Open University, press. 